\title{
Emergence and biomass accumulation in seedlings of rice cultivars irrigated with saline water
}

\author{
Márcio H. da C. Freire ${ }^{1}$, Geocleber G. de Sousa ${ }^{1}$, Maria V. P. de Souza ${ }^{1}$, \\ Emanuel D. R. de Ceita ${ }^{1}$, Jamili N. Fiusa ${ }^{1} \&$ Kelly N. Leite ${ }^{2}$
}

\begin{abstract}
${ }^{1}$ Universidade da Integração Internacional da Lusofonia Afro-Brasileira/Instituto de Desenvolvimento Rural/Curso de Agronomia. Redenção, CE. E-mail: marciohcfreire@gmail.com (Corresponding author) - ORCID: 0000-0002-5490-4115; sousasolosgeo@hotmail.com - ORCID: 0000-0002-1466-6458; vanessa.pires1993@gmail.com - ORCID: 0000-0003-3316-6093; emanuelceita@hotmail.com - ORCID: 0000-0002-9543-1094; miilinobre@hotmail.com ORCID: 0000-0002-2458-5010
\end{abstract}

${ }^{2}$ Universidade Federal do Acre. Cruzeiro do Sul, AC. E-mail: knleite.ufac@gmail.com - ORCID: 0000-0003-1919-9745

Key words:

Oryza sativa L. emergence

salt stress

\begin{abstract}
A B S T R A C T
The objective of this study was to evaluate the performance of three rice cultivars under saline water irrigation. The experiment was carried out in full sun at the Experimental Farm of the Unilab, in Redenção, Ceará, Brazil, in January 2016. The experimental design was completely randomized (CRD), in a $5 \times 3$ factorial scheme [irrigation water electrical conductivity (ECw: $0.5,1.0,2.0,3.0$ and $4.0 \mathrm{dS} \mathrm{m}^{-1}$ ) versus three rice cultivars $(\mathrm{C} 1$ Ligeirinho, C2 - Casado and C3 - Meruinho)], totaling 15 treatments, with 4 replicates of 30 seeds per cultivar. After 21 days, the following variables were evaluated: emergence percentage (EP), emergence speed index (ESI), mean time of emergence (MTE), mean speed of emergence (MSE), shoot dry matter (SDM), root dry matter (RDM) and total dry matter (TDM). The cultivar Ligeirinho showed higher tolerance to saline stress with respect to the emergence percentage, emergence speed index and mean speed of emergence. The cultivar Casado showed higher tolerance to saline stress for shoot dry matter, root dry matter and total dry matter in comparison to the other cultivars.
\end{abstract}

\section{Palavras-chave: Oryza sativa L. emergência estresse salino}

\section{Emergência e acúmulo de biomassa em plântulas de cultivares de arroz irrigadas com águas salinas}

\begin{abstract}
R E S U M O
Objetivou-se avaliar o desempenho de três cultivares de arroz sob salinidade da água de irrigação. O experimento foi conduzido a pleno sol na Fazenda Experimental da Unilab, Redenção, Ceará, em janeiro de 2016. O delineamento experimental foi inteiramente casualizado (DIC), com tratamentos arranjados em esquema fatorial, 5 x 3 [(condutividade elétrica da água de irrigação (CEa: 0,$5 ; 1,0 ; 2,0 ; 3,0$ e 4,0 dS m$~^{-1}$ ) aplicadas em três cultivares de arroz (C1- Ligeirinho; C2 - Casado e C3 - Meruinho)], totalizando 15 tratamentos, com 4 repetições de 30 sementes por cultivar. Após 21 dias, foram avaliadas as seguintes variáveis: porcentagem de emergência (PE), índice de velocidade de emergência (IVE), tempo médio de emergência (TME), velocidade média de emergência (VME), massa seca da parte aérea (MSPA), massa seca da raiz (MSR) e massa seca total (MST). A cultivar Ligeirinho possui maior tolerância ao estresse salino quanto à porcentagem de emergência, índice de velocidade de emergência e velocidade média de emergência. A cultivar Casado apresentou maior tolerância ao estresse salino para massa seca da parte aérea, raiz e total em relação às demais cultivares.
\end{abstract}




\section{INTRODUCTION}

Rice is one of the crops with highest technological levels nowadays, occupying prominent position from the economic and social points of view in Brazil, and its cultivation highly depends on irrigation water quality, which is directly linked to salinity and toxicity. According to Larré et al. (2014), salinity affects seed germination and vigor, not only hampering water absorption kinetics, but also facilitating the entry of ions at toxic levels in soaked seeds.

It is important to highlight that the nutritional stress on plants under salt stress may be associated with the excessive accumulation of certain ions and with the reduction in the acquisition of others, due to the alterations in nutrient availability, competition during absorption and transport inhibition in the plant (Neves et al., 2009; Souza et al., 2010).

The scientific community of areas affected by salts or where saline water is used in irrigation has been searching for alternative genotypes that can grow, develop and produce in these environments. These salts present in the irrigation water cause alterations in the germinative performance of seeds of various species (Larré et al., 2011). Thus, genetic improvement programs aiming to select genotypes that are tolerant to this abiotic stress are needed to concentrate efforts on the critical stages of the plant (Soares Filho et al., 2016). In this context, this study tried to find at least one rice cultivar tolerant to saline water during the stages of emergence and growth of seedlings.

It is worth highlighting that the effects of saline stress on plants lead to alterations in the osmotic potential and nutritional imbalance (Sousa et al., 2010; Gomes et al., 2011), compromising their physiological and biochemical functions (Calvet et al., 2013). This problem suggests the need for investigative studies on different rice cultivars with respect to tolerance to irrigation water salinity, as reported by Benitez et al. (2010).

Therefore, this study aimed to evaluate the performance of three rice cultivars under different levels of salinity.

\section{Material ANd Methods}

The experiment was carried out in full sun at the Experimental Farm of the University for International Integration of the Afro-Brazilian Lusophony (UNILAB), located at the Piroás Farm, belonging to the municipality of Redenção, Ceará, in the Baturité Massif region, in January 2016. According to Köppen's classification, the local climate is Aw', i.e., very hot rainy tropical, with predominance of rains in summer and autumn seasons.

The experimental design was completely randomized (CRD), with treatments arranged in a $5 \times 3$ factorial scheme, corresponding to five levels of irrigation water salinity (ECw: $0.5 ; 1.0 ; 2.0 ; 3.0$ and $4.0 \mathrm{dS} \mathrm{m}^{-1}$ ) and three rice cultivars (Ligeirinho - C1, Casado - C2 and Meruinho - C3), totaling 15 treatments, with 4 replicates of 30 seeds per cultivar.

In January 2016, the three rice cultivars were sown in EPS (expanded polystyrene) trays, and each one with 128 cells $\left(40 \mathrm{~cm}^{3}\right)$ received irrigation with a different level of salinity. Each cell received one seed, planted at $2 \mathrm{~cm}$ depth in substrate containing soil, sand and humus, at 1:1:1 proportion. Emergence was daily monitored by recording the number of emerged seedlings until 21 days after sowing (DAS), and the samples for biomass analysis were collected, separated, identified and dried in a forced-air oven to determine the dry weight in grams $(\mathrm{g})$.

Irrigation solutions with $\mathrm{ECw}=0.5 \mathrm{dS} \mathrm{\textrm {m } ^ { - 1 }}$ were prepared using $\mathrm{NaCl}, \mathrm{CaCl}_{2} \cdot 2 \mathrm{H}_{2} \mathrm{O}, \mathrm{MgCl}_{2} \cdot 6 \mathrm{H}_{2} \mathrm{O}$ salts, at 7:2:1 proportion, following the relationship between $\mathrm{ECw}$ and their respective concentrations $\left(\mathrm{mmol}_{\mathrm{c}} \mathrm{L}^{-1}=\mathrm{ECw} \times \mathrm{x} 10\right)$ (Rhoades et al., 2000). Irrigation was applied manually on a daily frequency.

To evaluate treatment effects, the following variables were analysed: emergence percentage (EP), determined until 21 DAS by counting the normal seedlings; emergence speed index (ESI), determined by daily counting the seedlings according to the methodology recommended by Maguire (1962); mean time of emergence (MTE), determined by daily counting the seeds according to the methodology proposed by Labouriau (1983), with results expressed in days; mean speed of emergence (MSE), determined according to the methodology proposed by Carvalho \& Carvalho (2009), with result also expressed in days. In addition, shoot dry matter (SDM), root dry matter (RDM) and total dry matter (TDM) were also evaluated, with results expressed in grams (g).

The results were subjected to analyses of variance and regression for water electrical conductivity and means were compared by Tukey test for the cultivars $(\mathrm{p}<0.05)$, using the program Assistat 7.6 Beta. In the regression analysis, equations were chosen based on the significance of the regression coefficients at $0.01\left(^{* *}\right)$ and $0.05\left(^{*}\right)$ probability levels by $\mathrm{F}$ test, and on the highest coefficient of determination $\left(\mathrm{R}^{2}\right)$.

\section{Results AND Discussion}

The interaction between salinity and cultivars had significant effect on all variables evaluated, namely: emergence percentage, emergence speed index, mean time of emergence, mean speed of emergence, shoot dry matter, root dry matter and total dry matter (Table 1).

Table 1. Summary of the analysis of variance (ANOVA) for emergence percentage (EP), emergence speed index (ESI), mean time of emergence (MTE), mean speed of emergence (MSE), shoot dry matter (SDM), root dry matter (RDM) and total dry matter (TDM) of rice cultivars grown at different levels of irrigation water salinity

\begin{tabular}{|c|c|c|c|c|c|c|c|c|}
\hline \multirow{2}{*}{ SV } & \multirow{2}{*}{ DF } & \multicolumn{7}{|c|}{ Mean squares } \\
\hline & & EP & ESI & MTE & MSE & SDM & RDM & TDM \\
\hline Cultivars (C) & 2 & $330.91^{\mathrm{ns}}$ & $1.93^{\mathrm{ns}}$ & $31.15^{\text {** }}$ & $0.01^{*}$ & $0.32^{* *}$ & $0.06^{\text {** }}$ & $0.30^{* *}$ \\
\hline Salinity (S) & 4 & $173.48^{\text {ns }}$ & $1.13^{\mathrm{ns}}$ & $8.97^{\text {ns }}$ & $0.002^{\mathrm{ns}}$ & $0.02^{\mathrm{ns}}$ & $0.01^{\mathrm{ns}}$ & $0.02^{\text {ns }}$ \\
\hline $\mathrm{C} \times \mathrm{S}$ & 8 & $2939.54^{* *}$ & $11.18^{\text {** }}$ & $46.76^{* *}$ & $0.02^{\text {** }}$ & $0.32^{* *}$ & $0.38^{* *}$ & $1.11^{* *}$ \\
\hline Residual & 40 & 35.737 .81 & 236.32 & 381.52 & 0.002 & 0.01 & 0.01 & 0.03 \\
\hline CV (\%) & - & 38.88 & 35.58 & 38.71 & 36.67 & 37.59 & 32.75 & 27.93 \\
\hline
\end{tabular}

SV - Source of variation; DF - Degrees of freedom; CV - Coefficient of variation; ${ }^{*}$ Significant at 0.01 probability level; ${ }^{*}$ Significant at 0.05 probability level; ns Not significant ( $p \geq 0.05$ ) 
Regarding emergence percentage (Figure 1A), for the cultivars Casado and Meruinho, the linear model showed the best fit, whereas a polynomial model fitted best to the data of the cultivar Ligeirinho, with maximum EP estimated at $65.06 \%$ when $1.5 \mathrm{dS} \mathrm{m}^{-1}$ water was used for irrigation.

The negative effect of saline stress (Figure 1A) may be related to the reduction in the osmotic potential of the substrate, hampering water absorption by seeds. Subsequently, the processes of cell division and elongation are also compromised, as well as the mobilization of reserves that are essential to germination and, consequently, emergence speed index (Pereira et al., 2012; Coelho et al., 2014).

Similar results with the cultivar BRS Querência were found by Larré et al. (2014), who observed reduction in the emergence of rice seeds irrigated with saline solutions. Likewise, Brunes et al. (2013) found negative effect of saline stress on the emergence percentage of oat seeds.

According to Figure 1B, the quadratic polynomial model fitted best to the data, and maximum emergence speed index (ESI) was equal to 0.34 seedlings day ${ }^{-1}$ for the cultivar Casado irrigated with $3.8 \mathrm{dS} \mathrm{m}^{-1}$ water; to 2.8 seedlings day ${ }^{-1}$ for the cultivar Meruinho irrigated with $1.98 \mathrm{dS} \mathrm{m}^{-1}$ water; and to 4.32 seedlings day ${ }^{-1}$ for the cultivar Ligeirinho irrigated with $1.63 \mathrm{dS} \mathrm{m}^{-1}$ water. These results confirm that the effect of salinity varies according to the genetic material.

These reductions in ESI due to saline stress were also found by Larré et al. (2014), working with the rice cultivars BRS Bojurú and BRS Querência.
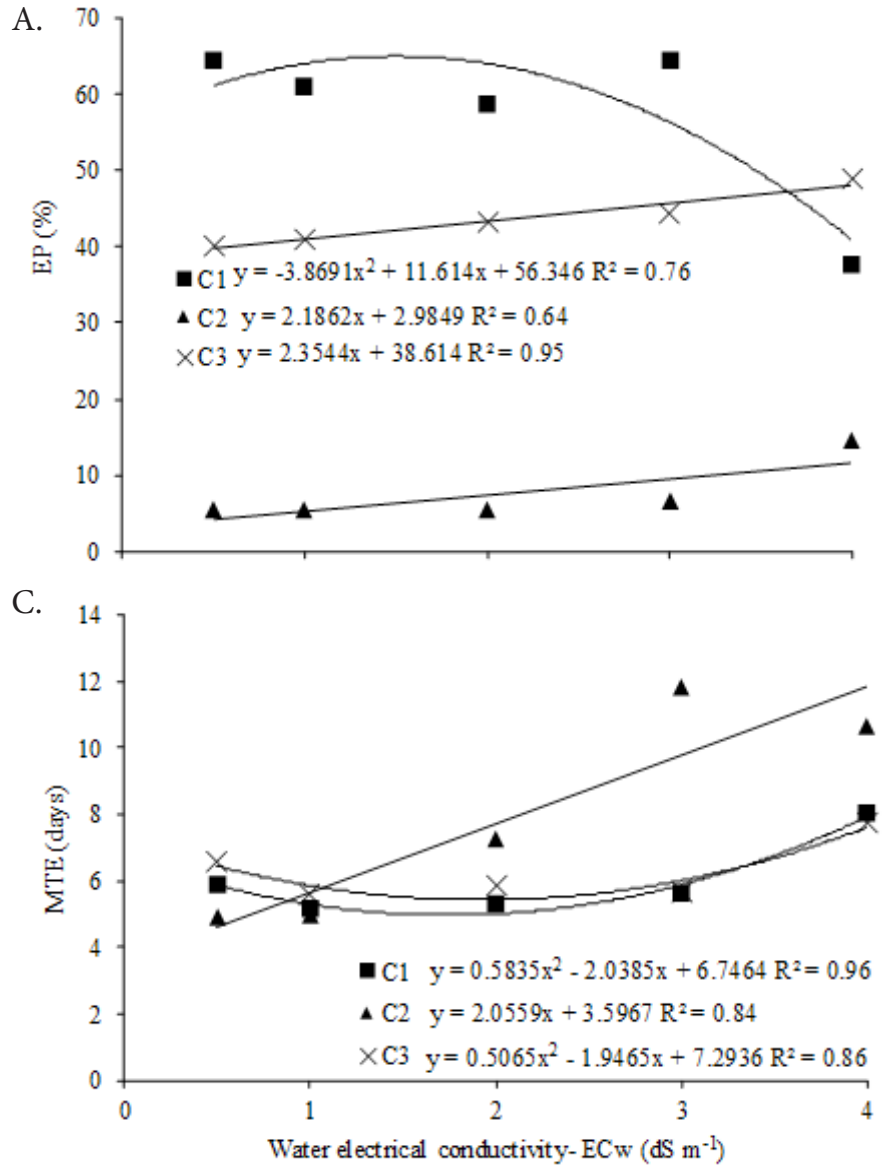

For the mean time of emergence, a quadratic polynomial model fitted best to the data of the cultivars Ligeirinho and Meruinho (Figure 1C), and the values decreased to 4.97 and 5.42 days, respectively, as the ECw increased up to 1.75 and $1.92 \mathrm{dS} \mathrm{m}^{-1}$, demonstrating higher resistance to the salts, compared with the cultivar Casado, described by a linear model.

The delay in emergence may be a result of the reduction in the osmotic potential of the soil solution, caused by the increase in the concentration of soluble salts, negatively interfering with soil water availability and, consequently, with water absorption by seeds (Santos et al., 2011). Rabbani et al. (2013) also found the similar results for the mean time of emergence in the sunflower crop irrigated with saline water.

For the mean speed of emergence (Figure 1D), all cultivars were negatively affected by the increase in salt contents, and their behavior was described by a quadratic polynomial model with maximum points of 0.21 days at $\mathrm{ECw} 1.79 \mathrm{dS} \mathrm{m}^{-1}$ for Ligeirinho and 0.19 days at ECw of $1.98 \mathrm{dS} \mathrm{m}^{-1}$ for Meruinho. A quadratic polynomial model also fitted best to the data of the cultivar Casado, with $\mathrm{R}^{2}=0.47$, as shown in Eq. 1 :

$$
y=-0.0099 x^{2}+0.047 x+0.0652
$$

This result agrees with claims of Demontiêzo et al. (2016), who reported that $\mathrm{NaCl}$ addition contributes to delaying seedling emergence and can arguably be a preponderant factor in the mean speed of emergence of this species. Similar results were found by Rabani et al. (2013) in sunflower plants, whose
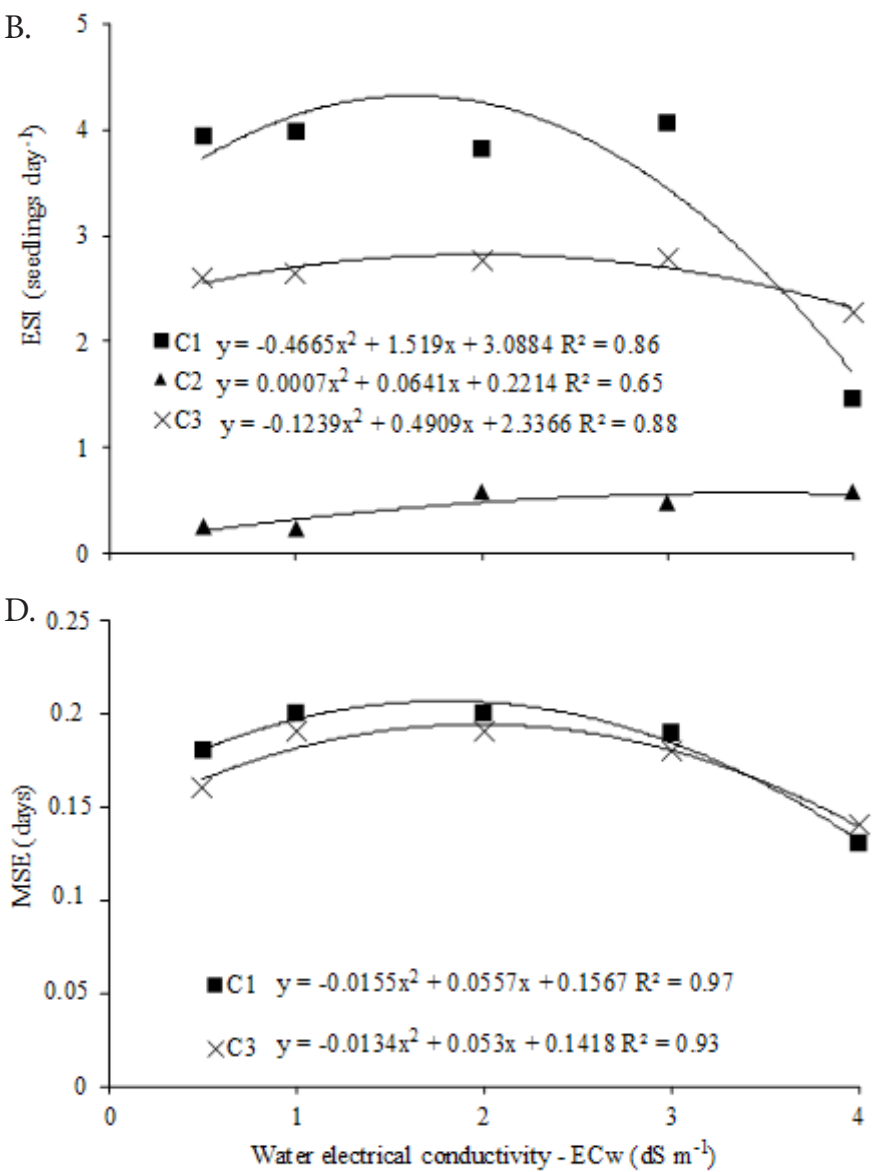

Figure 1. Emergence percentage - EP (A), emergence speed index - ESI (B), mean time of emergence - MTE (C) and mean speed of emergence - MSE (D) of rice cultivars (C1 - Ligeirinho, C2 - Casado; C3 - Meruinho) subjected to different salinity levels 
mean speed of emergence was also reduced by increments in irrigation water salinity. Conversely, Oliveira et al. (2015b) found that saline stress ranging from 0.6 to $5.0 \mathrm{dS} \mathrm{m}^{-1}$ led to increase in the mean speed of emergence in the beet crop.

Regarding seedling growth, assessed by shoot dry matter, highest performance was found at the lowest water salinity level $\left(0.5 \mathrm{dS} \mathrm{m}^{-1}\right)$ for the cultivar Casado, whereas a linear reduction occurred for the cultivar Meruinho as the saline stress increased (Figure 2A). The cultivar Ligeirinho showed $\mathrm{R}^{2}=0.48$ and the values were described by Eq. 2 :

$$
y=-0.1172 x+0.1681
$$

Possibly, the salts present in the irrigation water negatively affected the synthesis and translocation of hormones from roots to shoots, essential to leaf metabolism, which results in the loss of leaf area and, consequently, of shoot dry matter (Taiz \& Zeiger, 2013; Oliveira et al., 2015a).
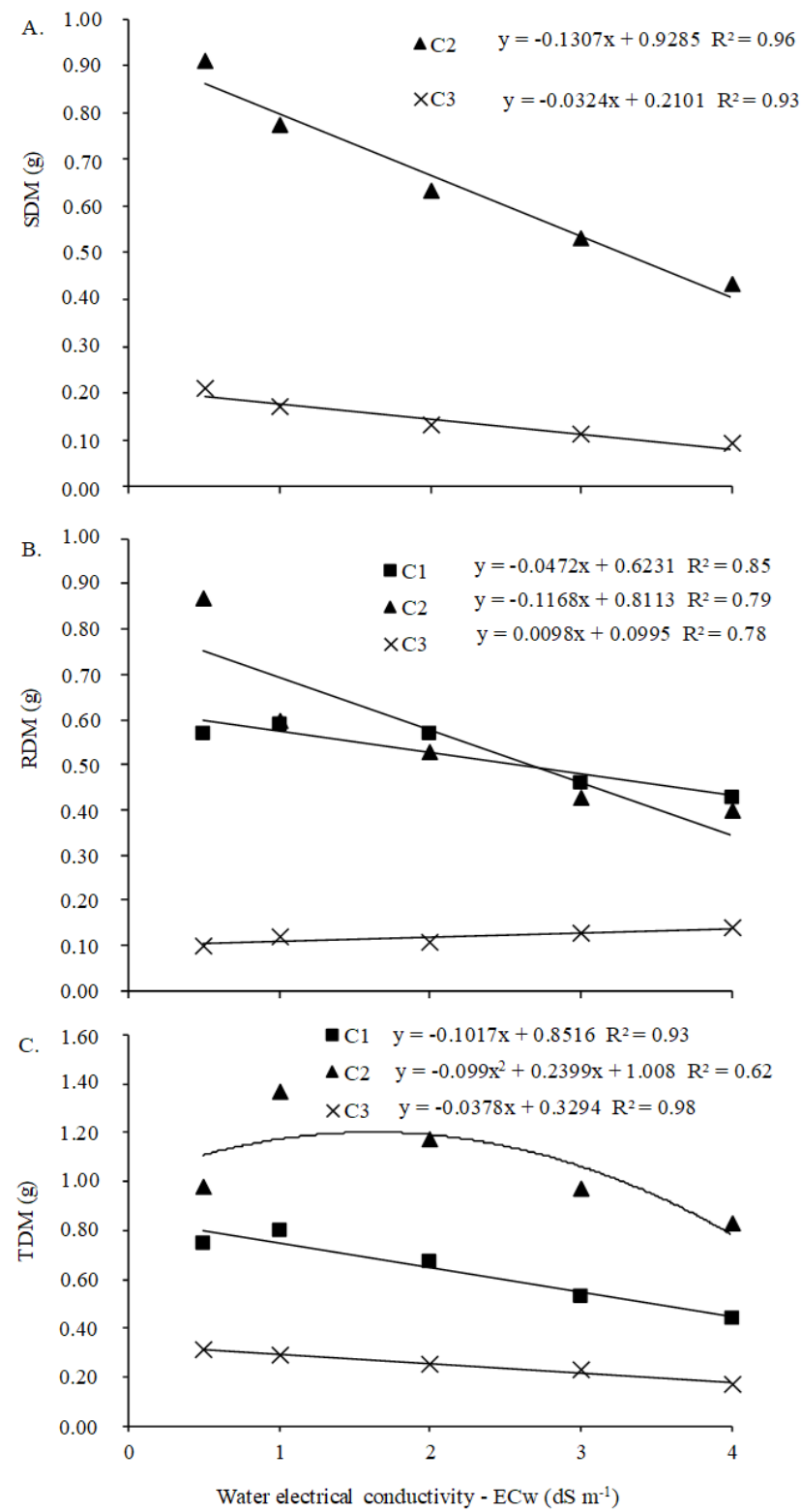

Figure 2. Shoot dry matter - SDM (A), root dry matter - RDM (B) and total dry matter - TDM (C) of rice cultivars (C1 Ligeirinho, C2 - Casado and C3 - Meruinho) subjected to different salinity levels
Benitez et al. (2010), evaluating the tolerance of rice genotypes to salinity as a function of different salinity levels, found reduction in seedling shoot dry matter as the saline stress increased. Similarly, Larré et al. (2014) evaluated the rice cultivar BRS Querência and found reduction in shoot dry matter as a function of salinity.

For root dry matter (Figure 2B), a decreasing linear model fitted best to the data of the cultivars Ligeirinho and Casado, whereas the behavior of Meruinho was described by an increasing linear model. Similar trends to those of Ligeirinho and Casado were found by Larré et al. (2014) in the rice cultivars BRS Querência and BRS Bojurú. These authors reported that the increment of $\mathrm{NaCl}$ concentration in the irrigation water reduced root dry matter. For the cultivar Meruinho, this increase in RDM may be a mechanism of tolerance to salts, i.e., the cultivar produced more roots to absorb the salts and prevent them from reaching the leaves, improving the redistribution of salts through its photoassimilates, thus avoiding greater toxicity.

For the total dry matter, the linear model fitted best to the data of the cultivars Ligeirinho and Meruinho, whereas a quadratic polynomial model fitted best to the data of the cultivar Casado, with maximum TDM of $1.2 \mathrm{~g}$ obtained at salinity of $1.20 \mathrm{dS} \mathrm{m}^{-1}$ (Figure 2C).

This effect may be related to physiological and hormonal disorders caused by irrigation water salinity (Calvet et al., 2013; Taiz \& Zaiger, 2013), reducing the synthesis of carbohydrates in the plant and its dry matter accumulation.

In agreement with the results, Santos et al. (2011) studied the peanut crop and found that the presence of $\mathrm{NaCl}$ negatively interfered with its total dry matter. Likewise, Prazeres et al. (2015) also observed negative effect on the total dry matter of cowpea plants irrigated with saline water.

\section{Conclusions}

1. The cultivar Ligeirinho has higher tolerance to saline stress with respect to emergence percentage, emergence speed index and mean speed of emergence.

2. The cultivar Casado showed higher tolerance to saline stress for shoot dry matter, root dry matter and total dry matter, in comparison to the others.

\section{Literature Cited}

Benitez, L. C.; Peters, J. A.; Bacarin, M. A.; Kopp, M. M.; Oliveira, A. C. de; Magalhães Júnior, A. M. de; Braga, E. J. B. Tolerância à salinidade avaliada em genótipos de arroz cultivados in vitro. Revista Ceres, v.57, p.330-337, 2010. https://doi.org/10.1590/ S0034-737X2010000300007

Brunes, A. P.; Fonseca, D. A. R.; Rufino, C. de A.; Tavares, L. C.; Tunes, L. M.; Villela, F. A. Crescimento de plântulas de aveia branca submetidas ao estresse salino. Semina: Ciências Agrárias, v.34, p.3455-3462, 2013. https://doi.org/10.5433/16790359.2013v34n6Supl1p3455

Calvet, A. S. F.; Pinto, C. de M.; Lima, R. E. M.; Maia-Joca, R. P. M.; Bezerra, M. A. Crescimento e acumulação de solutos em feijãocaupi irrigado com águas de salinidade crescente em diferentes fases de desenvolvimento. Irriga, v.18, p.148-159, 2013. https:// doi.org/10.15809/irriga.2013v18n1p148 
Carvalho, D. B. de; Carvalho, R. I. N. de. Qualidade fisiológica de sementes de guanxuma em influência do envelhecimento acelerado e da luz. Acta Scientiarum. Agronomy, v.31, p.489-494, 2009. https://doi.org/10.4025/actasciagron.v31i3.585

Coelho, D. S.; Simões, W. L.; Mendes, A. M. S.; Dantas, B. F.; Rodrigues, J. A. S.; Souza, M. A. de. Germinação e crescimento inicial de variedades de sorgo forrageiro submetidas ao estresse salino. Revista Brasileira de Engenharia Agrícola e Ambiental, v.18, p.25-30, 2014. https://doi.org/10.1590/S1415-43662014000100004

Demontiêzo, F. L. L.; Aragão, M. F.; Valnir Junior, M.; Moreira, F. J. C.; Paiva, P. V. V.; Lima, S. C. R. V. Emergência e crescimento inicial de tomate 'Santa Clara' em função da salinidade e condições de preparo das sementes. Irriga, v.1, p.81-92, 2016. https://doi. org/10.15809/irriga.2016v1n1p81-92

Gomes, K. R.; Amorim, A. V.; Ferreira, F. J.; Andrade Filho, F. L.; Lacerda, C. F.; Gomes Filho, E. Respostas de crescimento e fisiologia do milho submetido a estresse salino com diferentes espaçamentos de cultivo. Revista Brasileira de Engenharia Agrícola e Ambiental, v.15, p.365-370, 2011. https://doi. org/10.1590/S1415-43662011000400006

Labouriau, L. G. A germinação das sementes. Washington: OEA, 1983. $147 \mathrm{p}$.

Larré, C. F.; Marini, P.; Moraes, C. L.; Amarante, L. do; Moraes, D. M. de. Influência do 24-epibrassinolídeo na tolerância ao estresse salino em plântulas de arroz. Semina: Ciências Agrárias, v.35, p.67-76, 2014. https://doi.org/10.5433/1679-0359.2014v35n1p67

Larré, C. F.; Moraes, D. M. de; Lopes, N. F. Qualidade fisiológica de sementes de arroz tratadas com solução salina e 24-epibrassinolídeo. Revista Brasileira de Sementes, v.33, p.86-94, 2011. https://doi. org/10.1590/S0101-31222011000100010

Maguire, J.D. Speed of germination-aid in selection and evaluation for seedling emergence and vigor. Crop Science, v.2, p.176-177, 1962. https://doi.org/10.2135/cropsci1962.0011183X000200020033x

Neves, A. L. R.; Lacerda, C. F. de; Guimarães, F. V. A.; Hernandez, F. F. F.; Silva, F. B. da; Prisco, J. T.; Gheyi, H. R. Acumulação de biomassa e extração de nutrientes por plantas de feijãode-corda irrigadas com água salina em diferentes estádios de desenvolvimento. Ciência Rural, v.39, p.758-765, 2009. https:// doi.org/10.1590/S0103-84782009005000014

Oliveira, F. de A.; Sá, F. V. da S.; Paiva, E. P. de; Araújo, E. B. G. de; Silva, M. K. do N.; Andrade, R. A. de; Moreira, R. C. L.; Souto, L. da S. Emergência e crescimento inicial de plântulas de repolho cv. Chato de Quintal sob estresse salino. Revista Agropecuária Técnica, v.36, p.273-279, 2015a.
Oliveira, F. de A.; Sá, F. V. da S.; Paiva, E. P. de; Araújo, E. B. G. de; Souto, L. da S.; Andrade, R. A. de; Silva, M. K. N. do. Emergência e crescimento inicial de plântulas de beterraba cv. Chata do Egito sob estresse salino. Agropecuária Científica no Semiárido, v.11, p.1-6, 2015b.

Pereira, A. de M.; Queiroga, R. C. F. de; Silva, G. D. da; Nascimento, M. das G. R. do; Andrade, S. E. O. de. Germinação e crescimento inicial de meloeiro submetido ao osmocondicionamento da semente com $\mathrm{NaCl}$ e níveis de salinidade da água. Revista Verde de Agroecologia e Desenvolvimento Sustentável, v.7, p.205-211, 2012.

Prazeres, S. S.; Lacerda, C. F. de; Barbosa, F. E. L.; Amorim, A. V.; Araujo, I. C. da S.; Cavalcante, L. F. Crescimento e trocas gasosas de plantas de feijão-caupi sob irrigação salina e doses de potássio. Revista Agro@mbiente On-line, v.9, p111-118, 2015.

Rabbani, A. R. C.; Silva-Mann, R.; Ferreira, R. A.; Carvalho, S. V. A.; Nunes, F. B. S.; Brito, A. S. Efeito do estresse salino sobre atributos da germinação de sementes de girassol. Scientia Plena, v.9, p.12-23, 2013.

Rhoades, J. D.; Kandiah, A.; Mashali, A. M. Uso de águas salinas para produção agrícola. Campina Grande: UFPB, 2000. 117p. Estudos FAO - Irrigação e Drenagem, 48

Santos, A. R. F. dos; Silva-Mann, R.; Ferreira, R. A.; Brito, A. de S. Water pre-hydration as priming for Moringa oleifera Lam. seeds under salt stress. Tropical and Subtropical Agroecosystems, v.14, p.201-207, 2011.

Soares Filho, W. dos S.; Gheyi, H. R.; Brito, M. E. B.; Nobre, R. G.; Fernandes, P. D.; Miranda, R. de S. Melhoramento genético e seleção de cultivares tolerantes à salinidade. In: Gheyi, H. R.; Dias, N. da S.; Lacerda, C. F. de; Gomes Filho, E. Manejo da salinidade na agricultura: Estudos básicos e aplicados. 2.ed. Fortaleza: INCTSal, 2016. Cap.17, p.259-274.

Sousa, G. G. de; Lacerda, C. F. de; Cavalcante, L. F.; Guimarães, F. V. A.; Bezerra, M. E. de J.; Silva, G. L. da. Nutrição mineral e extração de nutrientes de planta de milho irrigada com água salina. Revista Brasileira de Engenharia Agrícola e Ambiental, v.14, p.1143-1151, 2010. https://doi.org/10.1590/S1415-43662010001100003

Souza, Y. A.; Pereira, A. L.; Silva, F. F. S. da; Reis, R. C. R.; Evangelista, M. R. V.; Castro, R. D. de; Dantas, B. F. Efeito da salinidade na germinação de sementes e no crescimento inicial de mudas de Pinhão-manso. Revista Brasileira de Sementes, v.32, p.83-92, 2010. https://doi.org/10.1590/S0101-31222010000200010

Taiz, L.; Zeiger, E. Fisiologia vegetal. 5.ed. Porto Alegre: Artemed, 2013. 954p. 